\title{
NOTES ON EEL LARVAE (ANGUILLA ANGUILLA LINNAEUS, 1758) FROM THE CENTRAL AND EASTERN NORTH ATLANTIC AND ON GLASS EELS FROM THE EUROPEAN CONTINENTAL SHELF ${ }^{1}$ )
}

\author{
by \\ W. L. VAN UTRECHT \& M. A. HOLLEBOOM \\ Institute of Taxonomic Zoology (Zoölogisch Museum), University of Amsterdam, P.O. Box 20125, \\ 1000 HC Amsterdam, The Netherlands
}

\begin{abstract}
Eel larvae caught in the mid North Atlantic and along the continental slope off the Portuguese coast are studied together with samples of glass eels caught just before entering fresh water along the Dutch and French coasts.

During their migration from the mid Atlantic towards the continental slope the mean length of the larvae investigated increased from 56 to $66 \mathrm{~mm}$, while the mean diameter of their otoliths increased from 0.17 to $0.23 \mathrm{~mm}$. The animals from the mid Atlantic had three complete growth zones in their otoliths, while the majority of those from the continental slope had four complete growth zones.

The specimens from the mid Atlantic show typical larval aspects as e.g. position of the anus and reaction to preservation, this in contrast to most of the animals caught along the continental slope. In $70 \%$ of the latter the position of the anus is varying and they turned completely opaque after preservation in alcohol; the remaining animals showed all typical larval aspects.

In the glass eels the numbers of growth zones varied from two to six complete ones, about $40 \%$ of the animals having four or more growth zones in their otoliths.

The results indicate that the variation in age found in the glass eels most probably comes into existence along the continental slope, where a number of larvae lag behind in metamorphosis.

The growth zones in the otoliths seem to represent completed regular growth cycles which are supposed to be annual.
\end{abstract}

\section{RÉSUMÉ}

Sont étudiées des larves d'Anguille capturées dans la partie centrale de l'Atlantique Nord et le long du versant de la plate-forme continentale au large des côtes du Portugal, ainsi que des échantillons de civelles prélevés juste avant la pénétration dans les eaux douces, le long des côtes des Pays-Bas et de France.

1) This paper is dedicated to Dr. C. L. Deelder on the occasion of his retirement.
Pendant la migration des larves à partir du centre de l'Atlantique vers la plate-forme continentale, leur longueur moyenne augmente de 56 à $66 \mathrm{~mm}$, tandis que le diamètre moyen de leurs otolithes augmente de 0,17 à $0,23 \mathrm{~mm}$. Dans les otolithes des exemplaires capturés au centre de l'Atlantique il y a trois zones complètes de croissance, tandis qu'il y en a quatre dans la plupart de ceux du bord de la plate-forme continentale.

Les exemplaires de l'Atlantique central présentent des aspects typiques pour les larves, par exemple la position de l'anus et la réaction à préservation en alcool, tandis que dans $70 \%$ des exemplaires capturés le long du versant de la plate-forme continentale la position de l'anus est variable et ils deviennent complètement opaques après préservation en alcool (les autres $30 \%$ montrant les aspects typiques pour les larves).

Chez les civelles, le nombre de zones complètes de croissance dans les otolithes varie de deux à six, approximativement $40 \%$ des exemplaires ayant quatre zones ou plus.

Les résultats obtenus montrent que les différences d'âge trouvées chez les civelles se manifestent à partir du séjour le long du bord de la plate-forme continentale, car c'est ici qu'il se produit un retard dans la métamorphose d'un certain nombre de larves.

Les zones de croissance des otolithes semblent correspondre à des cycles de croissance dont on suppose qu'ils sont annuels.

\section{INTRODUCTION}

In the past, two possible spawning areas have been nominated for the European eel. Grassi (1896) supposed that eels spawned in deep water near the coast, in the Atlantic as well as in the Mediterranean. Schmidt (1923) postulated that they spawned in the Sargasso Sea; this idea was mainly based on the areas in which very small larvae were caught. In more recent years new theories have been developed without, however, giving a final solution of this problem. 
Schmidt's opinion - based on the increase in length of the leptocephali and the distribution of length classes in the North Atlantic was that they migrate towards the continental shelf in about three years. In his opinion their transport is passive by means of oceanic currents. Objections, however, can be put forward to this view, because it is known that objects can move from the western part of the North Atlantic towards the European continental shelf within one year. Moreover, leptocephali can swim vigorously, as observed when they are kept in tanks. Besides, new data and theories about oceanic currents and transport of water masses in the North Atlantic make it necessary to look again into the problem of the migration of eel larvae and glass eels towards the European continent.

One opinion is that the distribution of eel larvae in the North Atlantic is mainly determined by the Gulf Stream system. However, Worthington (1976) proposes two gyres in the West Atlantic, one forming the Sargasso Sea area (Gulf Stream) and one more to the north, between the Sargasso area and the Grand Banks. According to him there is no direct flow of water towards western Europe. The only northward flow he proposes is along the north-west African coast along Portugal into the Norwegian Sea. Both opinions do not correlate very well with the observed distribution of eel larvae, nor do they support the idea of passive transportation.

Tucker (1959) reviewed the problem and developed the theory that the European eel does not spawn in the Sargasso Sea. In his view the maturing eels could not reach this area because they do not feed anymore once maturation begins, and their energy reserves should be insufficient for swimming the considerable distance from western Europe to the area between about $50^{\circ} \mathrm{W}$ and $60^{\circ} \mathrm{W}$, and $20^{\circ} \mathrm{N}$ and $30^{\circ} \mathrm{N}$. They would die before reaching that area. He supported his view by the evidence that only a few maturing eels were caught beyond the continental shelf. This theory initiated considerable discussion (cf. Sinha \& Jones, 1975).
Concerning the migration over the North Atlantic, Harden Jones (1970: 77-80) stated that knowledge of the age of leptocephali taken in various areas, e.g. around the Azores, along the continental shelf of Europe and in the Mediterranean, is important.

As far as could be ascertained, the only data about the age of leptocephali and glass eels of $A$. anguilla are those from an initial study by Ehrenbaum \& Marukawa (1913), whereas Liew (1974) studied the otoliths of glass eels and elvers of $A$. rostrata (Lesueur).

The present paper deals with age determination of leptocephali (larvae) from the central North Atlantic and off the Portuguese coast, and of glass eels, caught along the Dutch and French coasts when they were about to enter fresh water.

\section{MATERIAL AND METHODS}

The leptocephali from the mid North Atlantic are caught during cruises of the Amsterdam Mid North Atlantic Plankton Expedition with the R.V.H.M. "Tydeman" ") held in 1980-1983 (fig. 1). The samples were taken in 1980 (44 specimens) and 1981 (9 specimens) with a combined opening-closing Rectangular Midwater Trawl (RMT $1+8$ ), developed by the Institute of Ocean Studies, between $55^{\circ}$ and $28^{\circ} \mathrm{N}$, along the $30^{\circ} \mathrm{W}$ meridian. The leptocephali caught off the Portuguese coast (fig. 1) were sampled during a cruise of the F.R.S. "Tridens" with a pelagic trawl in which a modified Isaacs Kidd net was mounted. In this case sampling took place just beyond the $1000 \mathrm{~m}$ depth line. For further details about the samples see table I; the samples taken with the R.V.H.M. "Tydeman" in 1980 are listed by Van Utrecht (1983: 230 ). In all cases the leptocephali were immediately preserved in $70 \%$ alcohol.

The glass eels studied were taken at random from a large series of samples caught in successive years at a number of localities along the Dutch coast, in a sampling program of the Eel Department of the Netherlands Institute for Fisheries Investigations (R.I.V.O.), IJmuiden (see Heermans \& Van Willigen, 1982). These samples were taken with a $1 \mathrm{~m}^{2}$ square net. In 1979 two more samples of glass eels, one taken near Nantes and one near Bordeaux, France, were added.

2) Amsterdam Mid North Atlantic Plankton Expedition (AMNAPE), Project 101 A. Report no. 20, supported by a grant of the Netherlands Ministry of Education and Sciences, N.Z.R. [Report no. 19 appeared in Bull. zoöl. Mus. Univ. Amsterdam, 10 (17): 129-152 (1985).] 
After measuring and weighing, the samples became available for further study. The deep-frozen samples were thawed in $70 \%$ alcohol. When this was completed, the animals were stored in fresh $70 \%$ alcohol. No formalin was used, in order to avoid etching or dissolution of the otoliths. From each sample of glass eels 100 animals were taken at random. After measuring total length and the dimension of the head, the sagittae were taken out and mounted on glass slides in Canada balsam. Microscopic examination was made with transmitted light at $450 \times$ magnification. Morphometric and meristic data of leptocephali and glass eels caught in the mid- and eastern North Atlantic in 1981 and 1982 are listed in table II.

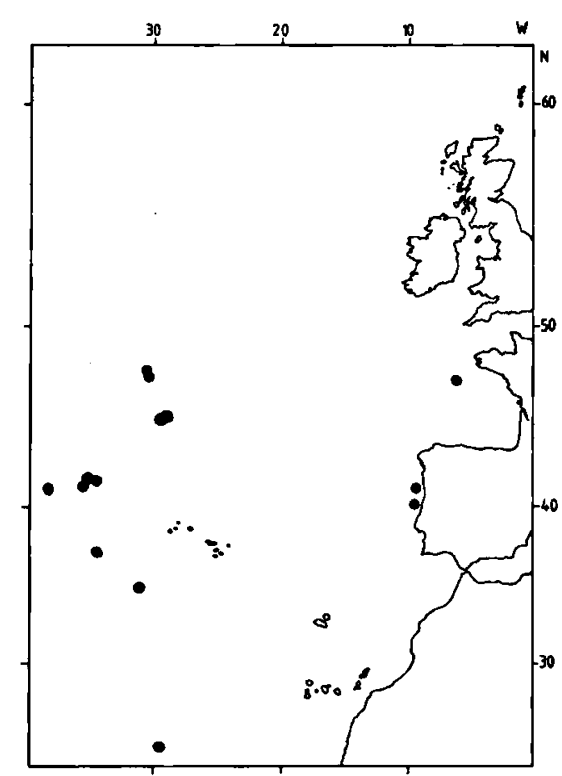

Fig. 1. Positions where larvae of $\boldsymbol{A}$. anguilla were taken.

The diameter of the otoliths was measured, the number of growth zones counted, and the distance from the centre of the otolith to the first opaque ring was measured, that from the first opaque ring to the second, and so on.

The otoliths (sagittae) from leptocephali and glass eels are more or less. flattened round bodies that are transparent in transmitted light. In the centre is a dark round spot or kernel. At a short distance from this spot is a dark circular ring.

This part is considered to be formed in the period from hatching to the moment the yolk reserves have gone. At that time, the larva has also the true leptocephalus form. Then follows a zone with patterns of circular light (translucent) and dark (opaque) rings (fig. 2). At certain distances from the centre, groups of two or three evidently thicker and darker rings, grouped close together, are present (fig. 2; in this figure the centre of the otolith is not well-defined, because it was out of focus when trying to get
TABLE I

Larval and metamorphosing eels caught in the mid- and eastern North Atlantic in 1981 and 1982.

Samples of leptocephali of $A$. anguilla taken by the Amsterdam Mid North Atlantic Plankton Expedition during the period September 15 - October 6, 1981 (R.V.H.M. "Tydeman") (cf. fig. 1). (ZMA = Zoölogisch Museum Amsterdam coll. no.)

Station 39; haul 2; 5-X-'81; 05.29-06.29 h; 55-100 m; $47^{\circ} 56.3^{\prime} \mathrm{N} 30^{\circ} 38.3^{\prime} \mathrm{W}$; (ZMA $119.158,3$ specimens).

Station 39; haul 10; 5-X-'81; 12.58-13.59 h; 405-500 m; $47^{\circ} 43.4^{\prime} \mathrm{N} 30^{\circ} 18.8^{\prime} \mathrm{W}$; (ZMA $119.159,1$ specimen).

Station 42; haul 9; 30-IX-'81; 15.01-16.02 h; 110-200 m; $41^{\circ} 44.7^{\prime} \mathrm{N} 34^{\circ} 25.0^{\prime} \mathrm{W}$; (ZMA $119.161,1$ specimen).

Station 43; haul 7; 29-IX-'81; 21.15-23.00 h; 0-421 m; $41^{\circ} 11.1^{\prime} \mathrm{N} 35^{\circ} 42.5^{\prime} \mathrm{W}$; (ZMA $119.160,1$ specimen).

Station 45; haul 1; 27-IX-'81; 10.21-11.21 h; 80-195 m; $37^{\circ} 09.0^{\prime} \mathrm{N} 34^{\circ} 48.6^{\prime} \mathrm{W}$; (ZMA $119.162,1$ specimen).

Station 47; haul 7; 24-IX-'81; 00.49-01.48 h; 95-190 m; $35^{\circ} 07.1^{\prime} \mathrm{N} 31^{\circ} 19.5^{\prime} \mathrm{W}$; (ZMA $119.163,1$ specimen).

Station 52; haul 11; 18-IX-'81; 17.32-18.33 h; 100-205 m; $25^{\circ} 02.3^{\prime} \mathrm{N} 29^{\circ} 58.2^{\prime} \mathrm{W}$; (ZMA $119.164,1$ specimen).

Samples of leptocephali and glass eels of $A$. anguilla taken during a fishing cruise of the F.R.S. "Tridens" from November 1 - November 6, 1982 (cf. fig. 1).

Station 1; haul 1; 1-XI-'82; 08.45-11.36 h; $340 \mathrm{~m}$; $40^{\circ} 01^{\prime} \mathrm{N} 09^{\circ} 45^{\prime} \mathrm{W}$; (ZMA 119.165, 1 specimen, in early stage of metamorphosis).

Station 1; haul 2; 1-XI-'82; 20.30-21.30 h; $50 \mathrm{~m}$; $41^{\circ} 10^{\prime} \mathrm{N} 09^{\circ} 26^{\prime} \mathrm{W}$; (ZMA $119.166,14$ specimens, of which 1 in early stage of metamorphosis).

Station 1; haul 3; 1-XI-'82; 22.05-23.30 h; $125 \mathrm{~m}$; $41^{\circ} 14^{\prime} \mathrm{N} 09^{\circ} 26^{\prime} \mathrm{W}$; (ZMA $119.167,10$ specimens, of which 2 in early stage of metamorphosis).

Station 3; haul 2; 2-XI-'82; 19.23-20.13 h; $50 \mathrm{~m}$; $47^{\circ} 10^{\prime} \mathrm{N} 06^{\circ} 08^{\prime} \mathrm{W}$; (ZMA 119.168, 2 specimens, glass eel stage).

the other growth features clearly defined). Such a group of thicker and darker rings is considered to mark as a border line the end of a growth cycle and the start of a next one, and is comparable to the "winter zone" as described by Liew (1974: fig. 4).

The zone of the otolith between two such border lines is optically less dense, by which the fine, very regularly interspaced, slightly darker lines in them become visible (fig. 2). These zones comprise the "summer zone" of Liew (Liew, 1974). In the translucent zones about 13 of these fine rings could be counted.

The part from one border line up to and including the next one is considered to represent a complete growth cycle or growth zone. There is no difference in shape and 


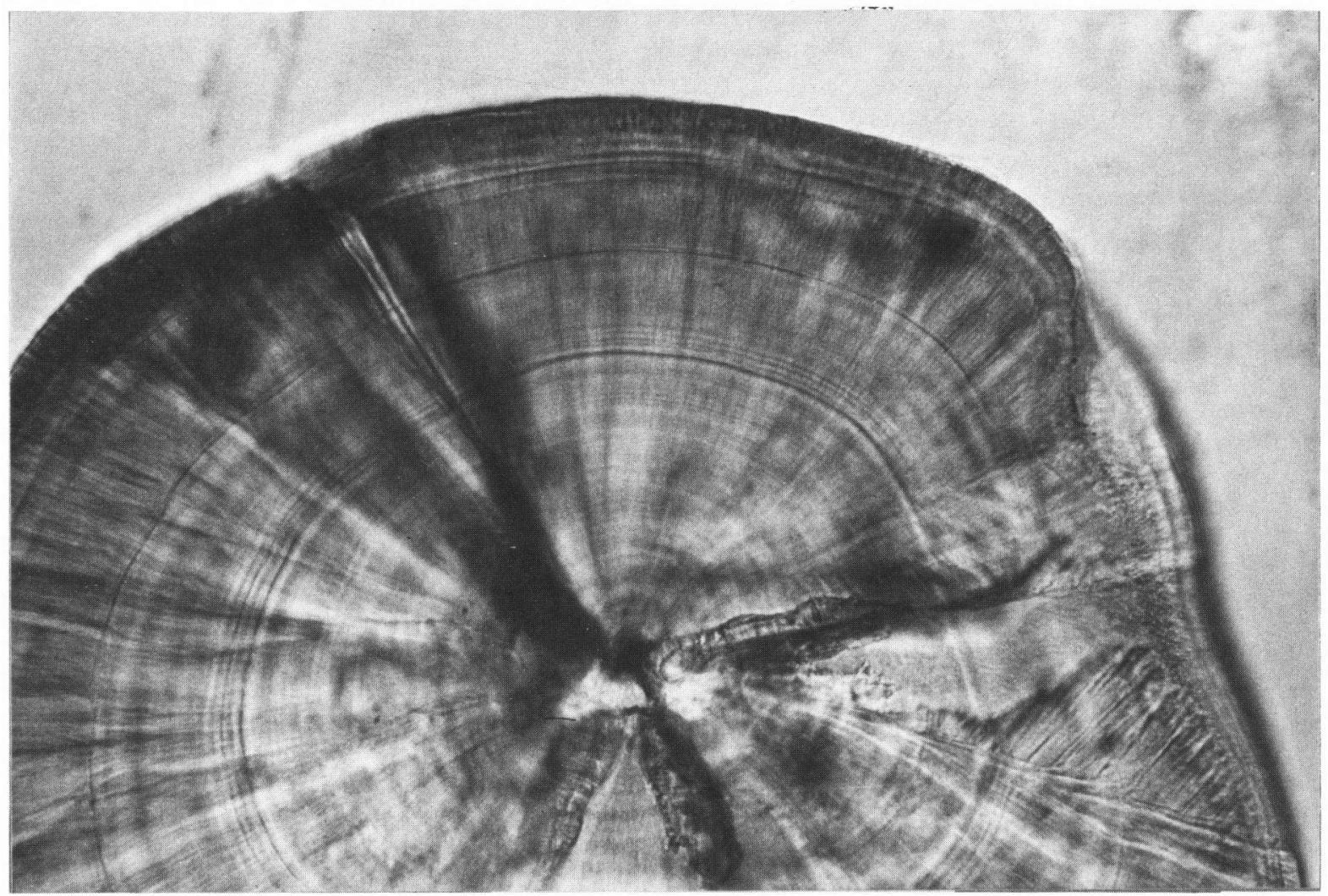

Fig. 2. Otolith of a glass eel showing two complete growth layers; diameter of the otolith $0.37 \mathrm{~mm}$. (Photo L. A. van der Laan.)

aspects between the otoliths of leptocephali and glass eels, except in the diameter and numbers of growth rings. The otoliths of the glass eels have a far greater diameter and consist of more complete growth zones.

\section{RESULTS}

\section{The eel larvae}

For the present study 78 leptocephali were available, 53 (from which 9 are used for studying the otoliths) of them were caught in the mid North Atlantic and 25 along the continental slope off the Portuguese coast (see table I and Van Utrecht, 1983: 230). ${ }^{3}$ )

3) From these 25 specimens from the continental slope off Portugal, 23 of two samples (ZMA coll. no. 119.166 and 119.167) were used for the calculations about mean width of the growth layers, standard deviation, etc. The other
The results of the myomere counts are given in table III. From the figures it is clear that most of the leptocephali belong to A. anguilla.

Though the numbers of leptocephali caught in the mid Atlantic and along the continental slope are small, they show clear differences in mean length. Those caught in the mid North Atlantic had a mean length of $56 \mathrm{~mm}$, they actually show a greater length than is generally supposed. Those caught along the continental slope had a mean length of $61.4 \mathrm{~mm}$. The mean length of four animals in early stage of metamorphosis was $66.3 \mathrm{~mm}$. From these figures it can be concluded that during their migration from the mid North Atlantic to the

specimens came from various localities in the mid North Atlantic and along the southern European continental slope. However, they all are incorporated in figs. 4 and 5 to demonstrate the continuity of the growth features in their otoliths. 
TABLE II

Morphometric and meristic data of leptocephali and glass eels caught in the mid-and eastern North Atlantic in 1981 and 1982.

\begin{tabular}{|c|c|c|c|c|c|c|c|c|}
\hline \multirow[t]{2}{*}{ position } & \multirow{2}{*}{$\begin{array}{l}\text { total } \\
\text { length } \\
\text { in } \mathrm{mm}\end{array}$} & \multirow{2}{*}{$\begin{array}{c}\text { tip snout } \\
- \\
\text { anus in } \mathrm{mm}\end{array}$} & \multirow{2}{*}{$\begin{array}{l}\text { length } \\
\text { postanal } \\
\text { part in } \\
\% \mathrm{TL}\end{array}$} & \multicolumn{3}{|c|}{$N$ of myomeres } & \multirow{2}{*}{$\begin{array}{c}N \text { of } \\
\text { growth } \\
\text { layers }\end{array}$} & \multirow[t]{2}{*}{ remarks } \\
\hline & & & & total & preanal & postanal & & \\
\hline $47^{\circ} 56^{\prime} \mathrm{N} 30^{\circ} 38^{\prime} \mathrm{W}$ & 54 & 36 & $34^{*}$ & 111 & 70 & 41 & $3+$ & \\
\hline do. & 59 & 41 & $31^{*}$ & 111 & 68 & 43 & $3+$ & \\
\hline do. & 60 & 42 & $30^{*}$ & 111 & 72 & 39 & $3+$ & \\
\hline $47^{\circ} 43^{\prime} \mathrm{N} 30^{\circ} 19^{\prime} \mathrm{W}$ & 63 & 42 & $34^{*}$ & 115 & 71 & 44 & $3+$ & \\
\hline $41^{\circ} 45^{\prime} \mathrm{N} 34^{\circ} 25^{\prime} \mathrm{W}$ & 63.5 & 42.5 & $33^{*}$ & 117 & 70 & 47 & - & \\
\hline $41^{\circ} 11^{\prime} \mathrm{N} 35^{\circ} 42^{\prime} \mathrm{W}$ & 61 & 43 & $30^{*}$ & 114 & 73 & 41 & - & \\
\hline $37^{\circ} 09^{\prime} \mathrm{N} 34^{\circ} 49^{\prime} \mathrm{W}$ & 52.2 & 36.3 & $31^{*}$ & 113 & 73 & 40 & - & \\
\hline $35^{\circ} 07^{\prime} \mathrm{N} 31^{\circ} 19^{\prime} \mathrm{W}$ & 52 & 36 & $31^{*}$ & 119 & 74 & 45 & $3+$ & \\
\hline $25^{\circ} 02^{\prime} \mathrm{N} 29^{\circ} 58^{\prime} \mathrm{W}$ & 52.8 & 32.6 & $38^{*}$ & 118 & 71 & 47 & - & \\
\hline $40^{\circ} 01^{\prime} \mathrm{N} 09^{\circ} 45^{\prime} \mathrm{W}$ & 58.5 & 24 & 58 & 118 & 36 & 82 & $3+$ & beginning metamorphosis \\
\hline $41^{\circ} 10^{\prime} \mathrm{N} 09^{\circ} 26^{\prime} \mathrm{W}$ & 58.5 & 26.3 & 55 & 118 & 46 & 72 & $4+$ & \\
\hline do. & 64 & 31.9 & 50 & 112 & 48 & 64 & $4+$ & \\
\hline do. & 59 & 40 & $32^{*}$ & 115 & 72 & 43 & $4+$ & \\
\hline do. & 64 & 37.8 & 41 & 115 & 45 & 70 & $4+$ & beginning metamorphosis \\
\hline do. & 59 & 40.4 & $32^{*}$ & 114 & 70 & 44 & $3+$ & \\
\hline do. & 61 & 41 & $33^{*}$ & 118 & 76 & 42 & $4+$ & \\
\hline do. & 62 & 43.4 & $30^{*}$ & 115 & 73 & 42 & $4+$ & \\
\hline do. & 50.3 & 34.4 & $32^{*}$ & 115 & 75 & 40 & - & \\
\hline do. & 57.5 & 27.0 & 53 & 113 & 46 & 67 & $4+$ & \\
\hline do. & 65.4 & 27.7 & 58 & 115 & 40 & 75 & $5+$ & \\
\hline do. & 58.7 & 27.4 & 53 & 118 & 48 & 70 & $3+$ & \\
\hline do. & 61.7 & 27.7 & 55 & 118 & 43 & 75 & $4+$ & \\
\hline do. & 62.8 & 24.5 & 61 & 115 & 38 & 77 & $4+$ & \\
\hline do. & 56.9 & 38.9 & $32^{*}$ & 117 & 63 & 54 & $4+$ & \\
\hline $41^{\circ} 14^{\prime} \mathrm{N} 09^{\circ} 26^{\prime} \mathrm{W}$ & 57.8 & 31.8 & 45 & 118 & 54 & 64 & $5+$ & \\
\hline do. & 63.2 & 43.8 & $31^{*}$ & 117 & 71 & 46 & $4+$ & \\
\hline do. & 64.6 & 31.7 & 51 & 113 & 48 & 65 & $4+$ & \\
\hline do. & 66.6 & 32.6 & 51 & 114 & 48 & 66 & $4+$ & \\
\hline do. & 63.3 & 25 & 61 & 119 & 34 & 85 & $4+$ & \\
\hline do. & 71 & 41 & 42 & 114 & 62 & 52 & $4+$ & \\
\hline do. & 70 & 31.5 & 55 & 118 & 41 & 77 & $4+$ & \\
\hline do. & 69.2 & 28.4 & 59 & 117 & 39 & 78 & $4+$ & beginning metamorphosis \\
\hline do. & 73.6 & 28.9 & 61 & 115 & 40 & 75 & $4+$ & beginning metamorphosis \\
\hline do. & 55.9 & 23.6 & 58 & 112 & 37 & 75 & $4+$ & \\
\hline 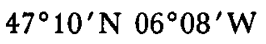 & 74.5 & 29.2 & 61 & & glass eel & & $4+$ & \\
\hline do. & 79.5 & 29.5 & 63. & & glass eel & & $4+$ & \\
\hline
\end{tabular}

* Specimen remaining transparent after preservation in alcohol.

continental slope they increase in length. The mean diameter of their otoliths increased from about $0.17 \mathrm{~mm}$ to $0.23 \mathrm{~mm}$.

A difference between the two samples of leptocephali appeared after preservation in $70 \%$ alcohol. In both cases the freshly caught animals were completely transparent. The animals from the mid North Atlantic remained more or less transparent so that the blood vessels and other internal structures remained visible. However, those caught along the continental slope turned completely white (opaque) 
TABLE III

Summary of the results of the myomere counts in 74 leptocephali.

\begin{tabular}{ccc}
\hline$N$ of myomeres & $N$ of specimens & $\%$ of total number \\
\hline 120 & - & - \\
119 & 3 & 4.1 \\
118 & 8 & 10.8 \\
117 & 5 & 5.8 \\
116 & 3 & 4.1 \\
115 & 12 & 15.2 \\
114 & 17 & 23.0 \\
113 & 13 & 17.6 \\
112 & 8 & 10.8 \\
111 & 3 & 4.1 \\
110 & 2 & 2.7 \\
109 & - & - \\
\hline
\end{tabular}

after preservation, so that no internal structures could be seen and counting of the myomeres had to be done with incident light. This was not the case with the marked animals in the lower part of table II, which also remained more or less transparent after preservation.

Ford (1931) examined leptocephali and glass eels of $A$. anguilla with respect to the change in position of the anus during metamorphosis. He found that in the leptocephalus the anus lies beyond the 71 th myomere and in the glass eel beyond the 35 th, while the postanal distance is more than $60 \%$ after metamorphosis.

Vladikov \& March (1975) mentioned that in the leptocephalus of $A$. anguilla there are 67-75 preanal myomeres and 38-48 postanal ones. Schoth (1982) found about the same figures.

From table II it is clear that the leptocephali in the samples from the mid North Atlantic all have a high preanal count and a postanal distance much shorter than $60 \%$ of the total length. In the samples taken along the continental slope this is quite different. Seven (marked *) out of 24 animals have a high number of preanal myomeres, and a low percentage of the postanal distance. In the other animals the number of preanal myomeres varied between 41 and 63 . Here the postanal distance varied between $41 \%$ and $61 \%$ of the total length.
Moreover, from table II it becomes clear that all specimens caught in the mid North Atlantic varied in length between $50 \mathrm{~mm}$ and about 65 $\mathrm{mm}$. Those caught along the continental slope showed a much greater variation between 55 $\mathrm{mm}$ and about $75 \mathrm{~mm}$ (see also fig. 3).

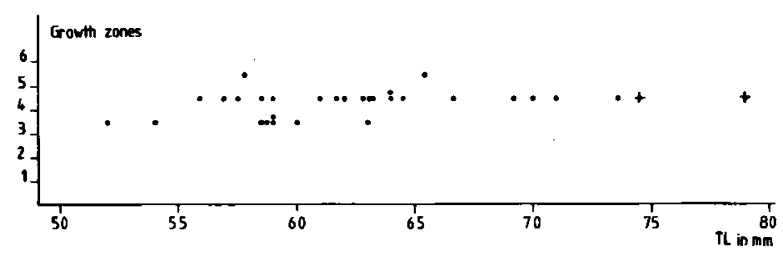

Fig. 3. Relation between the length of the eel larvae and the numbers of growth zones in their otoliths. The two animals marked + are true glass eels.

Likewise the counting of the otolith growth rings showed a clear difference between the animals from the mid North Atlantic and those from the continental slope. All animals caught in the mid North Atlantic had three complete growth rings, while far the greatest majority of those caught along the continental slope had four complete growth rings (table II).

The results of some calculations on the measurements of the width of the successive growth layers present in the otoliths of 23 eel larvae are given in table IV. From these data

\section{TABLE IV}

Width of the successive growth layers ( $\mathrm{mm}$ ) in the otoliths of eel larvae.

\begin{tabular}{cccccc}
\hline growth layer no. & $N$ & mean & variance & S.D. & S.E. \\
\hline 1 & 23 & 0.017 & 0.00009 & 0.010 & 0.002 \\
2 & 23 & 0.034 & 0.0001 & 0.010 & 0.002 \\
3 & 23 & 0.034 & 0.0001 & 0.007 & 0.001 \\
4 & 23 & 0.030 & 0.0001 & 0.009 & 0.002 \\
5 & 21 & 0.034 & 0.0002 & 0.016 & 0.003 \\
\hline
\end{tabular}

and from fig. 4 it can be concluded that the mean width of the growth layers is fairly constant. The data for the fifth growth zone show a greater variation, because in most animals this zone is still incomplete. 


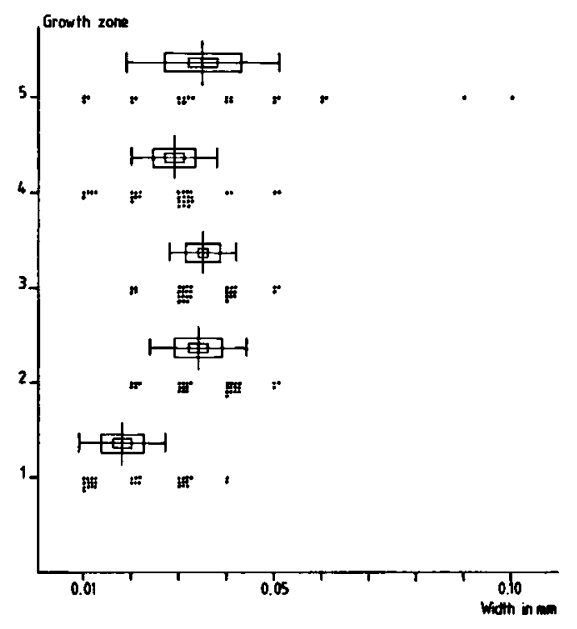

Fig. 4. Width of the successive growth zones in 32 eel larvae otoliths. The vertical line represents the arithmetic mean, the horizontal line the range. The outer box represents the standard deviation, the inner box the standard error.

The actual width of the growth layers varies between $0.01 \mathrm{~mm}$ and $0.05 \mathrm{~mm}$, though in most animals the width is about $0.035 \mathrm{~mm}$. It may be concluded that the growth of the otolith in the eel larvae is fairly constant in spite of individual variation. The same is found when the data are cumulated. Here the distances from the centre of the otolith to the consecutive (opaque) dark lines were measured. These data are plotted in fig. 5 and show a regular increase in diameter of the otolith of about $0.035 \mathrm{~mm}$ per growth cycle.

\section{The glass eels}

The mean lengths of the glass eels and the mean diameters of their otoliths are given in table $\mathrm{V}$. It is clear that the length of the animals varies considerably as is expressed in the high values of the variance and standard deviation. In fact, in all samples the lengths of the glass eels vary between 63 and $82 \mathrm{~mm}$. This great variation in length is certainly caused by the reduction in length and weight during the migration of the glass eels over the continental shelf (Gilson, 1908; Strubberg, 1913; Tesch, 1980). During this period they do not feed. This decrease in

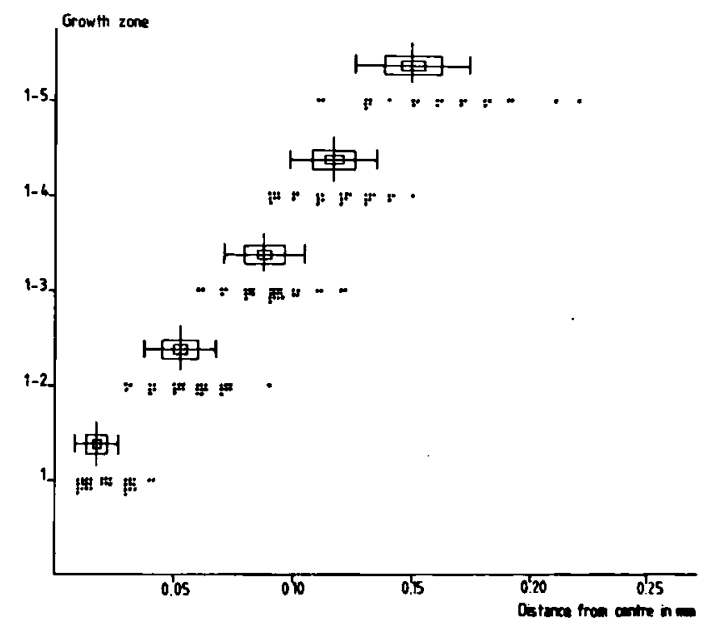

Fig. 5. Distance of the successive opaque border lines from the centre of the otolith in 32 eel larvae. For further explanation see fig. 4 .

length continues when they have entered fresh water and still do not feed (Deelder, 1970). From the same table it is also evident that the otoliths vary only slightly in diameter; their otoliths have a mean diameter of $0.33 \mathrm{~mm}$ to $0.35 \mathrm{~mm}$. The values for the standard deviation and variance are small.

The numbers of growth zones were counted in each of 973 otoliths from the samples mentioned in table $\mathrm{V}$ from animals caught along the Dutch coast. In table VI the numbers of complete growth zones are given, while the + sign indicates that the next zone is under formation. In one individual from the present series of samples only one complete growth zone was present, with a second zone partly formed. These data and fig. 6 show that about $60 \%$ of the animals had been through three complete growth cycles or less, and about $40 \%$ had four complete zones or more, before entering fresh water.

The relation of the age of the glass eels, expressed in growth zones, and their lengths, is plotted in fig. 7 for two samples, of which the sample "IJmuiden, 17-V-'79" is chosen for further analysis, together with two more samples, one taken near Nantes and the other 
TABLE V

Morphometric data of glass eels.

\begin{tabular}{|c|c|c|c|c|c|c|c|c|c|}
\hline & & \multicolumn{4}{|c|}{ length in $\mathrm{mm}$} & \multicolumn{4}{|c|}{ diameter left otolith } \\
\hline & & $N$ & mean & variance & S.D. & $N$ & mean & variance & S.D. \\
\hline IJmuiden & $31-V-' 78$ & 100 & 68.2 & 9.09 & 3.01 & 97 & 0.35 & 0.0009 & 0.03 \\
\hline IJmuiden & 22-III-'79 & 100 & 74.1 & 16.57 & 4.07 & 100 & 0.33 & 0.0004 & 0.02 \\
\hline Stellendam & 10-V-'79 & 100 & 71.7 & 6.20 & 2.49 & 99 & 0.33 & 0.0006 & 0.03 \\
\hline IJmuiden & 30-IV-'79 & 100 & 71.5 & 15.71 & 3.96 & 100 & 0.34 & 0.0005 & 0.02 \\
\hline Lauwersmeer & 28-V-'79 & 100 & 70.3 & 14.85 & 3.85 & 99 & 0.34 & 0.0004 & 0.02 \\
\hline Stellendam & 17-IV-'79 & 100 & 73.4 & 17.22 & 4.13 & 100 & 0.34 & 0.0006 & 0.02 \\
\hline IJmuiden & 10-IV-'79 & 81 & 74.2 & 14.62 & 3.82 & 81 & 0.35 & 0.0004 & 0.02 \\
\hline IJmuiden & 17-V-'79 & 100 & 71.7 & 12.14 & 3.48 & 100 & 0.35 & 0.0005 & 0.02 \\
\hline Stellendam & 28-III-’78 & 100 & 69.0 & 10.24 & 3.20 & 100 & 0.34 & 0.0004 & 0.02 \\
\hline Stellendam & 21-IV-'78 & 100 & 68.2 & 9.52 & 3.09 & 100 & 0.34 & 0.0004 & 0.02 \\
\hline Katwijk & 17-III-'78 & 100 & 69.1 & 11.38 & 3.37 & 100 & 0.35 & 0.0004 & 0.02 \\
\hline Katwijk & 12-IV-'78 & 100 & 67.5 & 7.48 & 2.73 & 100 & 0.34 & 0.0004 & 0.02 \\
\hline Bordeaux & 10-III-'79 & 100 & 72.9 & 20.83 & 4.54 & 95 & 0.34 & 0.0005 & 0.02 \\
\hline Nantes & 20-III-'79 & 65 & 74.0 & 17.25 & 4.12 & 44 & 0.34 & 0.0009 & 0.03 \\
\hline
\end{tabular}

near Bordeaux. The plots of the other samples are practically identical to each other. It is evident that no relation exists between the length of the glass eels and their age in growth zones. Nearly all length classes are present in each age group, and each length class comprises generally three or more age groups.

When looking through the series of otoliths, the width of the growth zones seems to be fairly constant. To verify this, the width of the layers of one sample of glass eels, "IJmuiden, 17-V'79' 'was measured. Although the otoliths from 100 individuals were available, accurate measurements could be taken from 83 otoliths.

\section{TABLE VI}

Numbers of growth zones in 973 left otoliths from samples of glass eels caught along the Dutch coast.

\begin{tabular}{ccc}
\hline $\begin{array}{c}N \text { of } \\
\text { growth zones }\end{array}$ & $\begin{array}{c}N \text { of } \\
\text { animals }\end{array}$ & $\begin{array}{c}\text { \% of total } \\
\text { number }\end{array}$ \\
\hline $1+$ & 1 & 0.1 \\
$2+$ & 210 & 21.7 \\
$3+$ & 371 & 38.1 \\
$4+$ & 291 & 29.9 \\
$5+$ & 87 & 8.9 \\
$6+$ & 13 & 1.3 \\
\hline
\end{tabular}

The results have been plotted in fig. 8. The figures for the mean, variance, standard deviation and standard error are given in table VII.

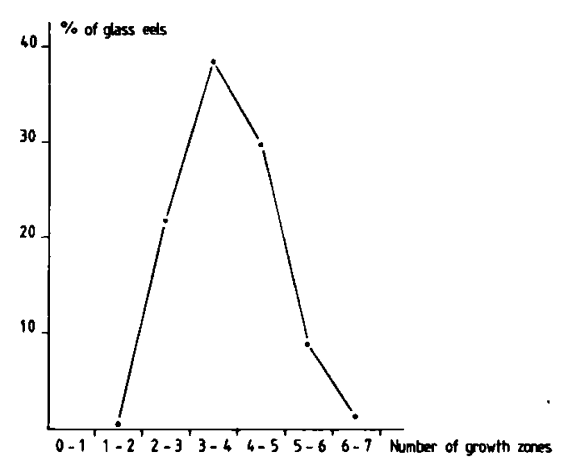

Fig. 6. Percentages of the total numbers of glass eels caught along the Dutch coast arranged according to the numbers of growth zones in their otoliths.

From these data and from fig. 8 one can conclude that the mean width of the growth zones is fairly constant, though the actual width varies between $0.01 \mathrm{~mm}$ and $0.1 \mathrm{~mm}$. However, most layers are $0.03 \mathrm{~mm}$ to $0.07 \mathrm{~mm}$ wide. So the growth of the otolith is fairly regular notwithstanding the individual variation. The same is found when the data are cumulated. The distances from the centre of the otolith to 


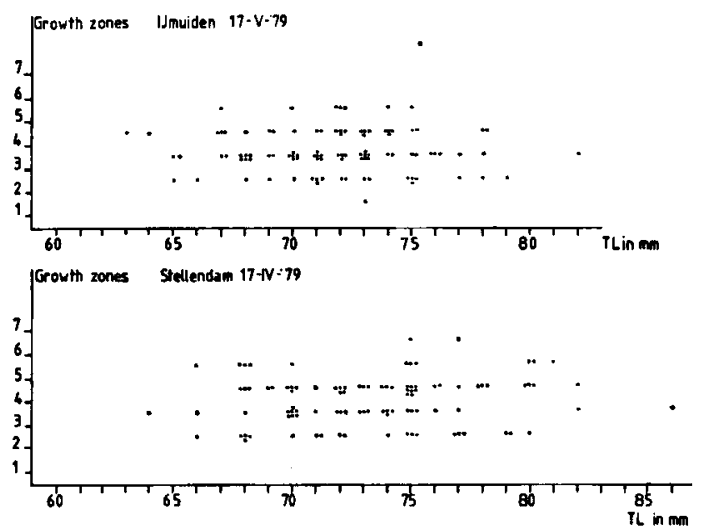

Fig. 7. The age-length relation plotted for two samples of glass eels from The Netherlands.

the consecutive (opaque) dark lines were measured. These data are plotted in fig. 9 and illustrate the regular increase in diameter of the otolith.

The same procedure is followed for the samples of glass eels from Nantes and Bordeaux. The mean lengths are given in table $\mathrm{V}$ together with the mean diameter of the otoliths. These figures are within the range of the samples from the Dutch coast. The mean diameter of the otoliths is $0.34 \mathrm{~mm}$ and is the same as for the animals caught along the Dutch coast.

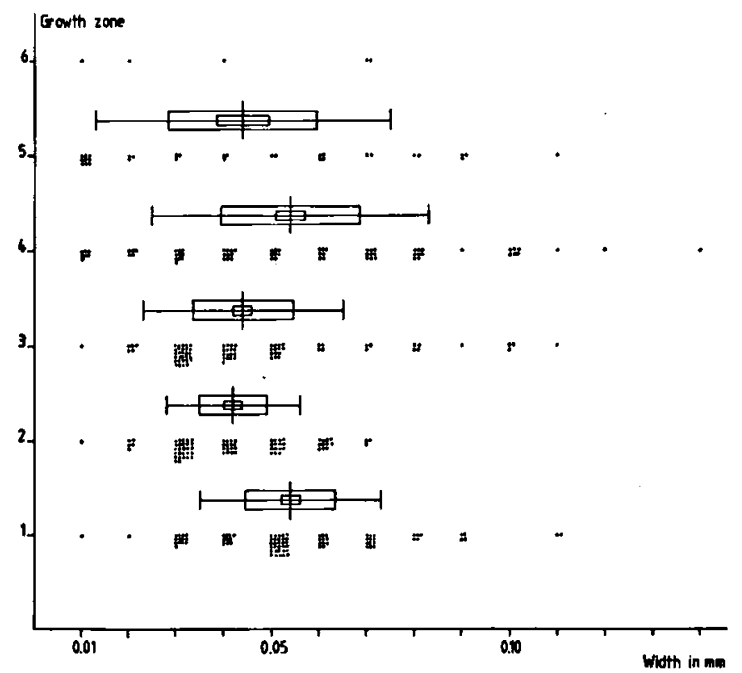

Fig. 8. Width of the successive growth zones in 83 glass eel otoliths from IJmuiden, caught 17-V-'79. For further explanation see fig. 4 .
In table VIII the results of the counting of growth zones in these two samples are given. These figures are plotted in fig. 10 and compared with the data from the sample of IJmuiden. The graphs for the sample from IJmuiden and Bordeaux are nearly identical. In both cases $60 \%$ or more animals went through

\section{TABLE VII}

Width of the successive growth layers ( $\mathrm{mm}$ ) in the otoliths of 83 glass eels from IJmuiden, caught 17-V-'79.

\begin{tabular}{cccccc}
\hline growth layer no. & $N$ & mean & variance & S.D. & S.E. \\
\hline 1 & 83 & 0.054 & 0.0004 & 0.019 & 0.002 \\
2 & 83 & 0.042 & 0.0002 & 0.014 & 0.002 \\
3 & 82 & 0.044 & 0.0004 & 0.021 & 0.002 \\
4 & 75 & 0.054 & 0.0009 & 0.029 & 0.003 \\
5 & 30 & 0.044 & 0.0009 & 0.031 & 0.006 \\
\hline
\end{tabular}

three complete growth zones or less before entering fresh water. In the sample from Nantes the curve has shifted to four complete growth cycles before entering fresh water. The reason of this shift is not clear. However, the sample of glass eels from Nantes consisted of less than half the number of that in the two other samples.

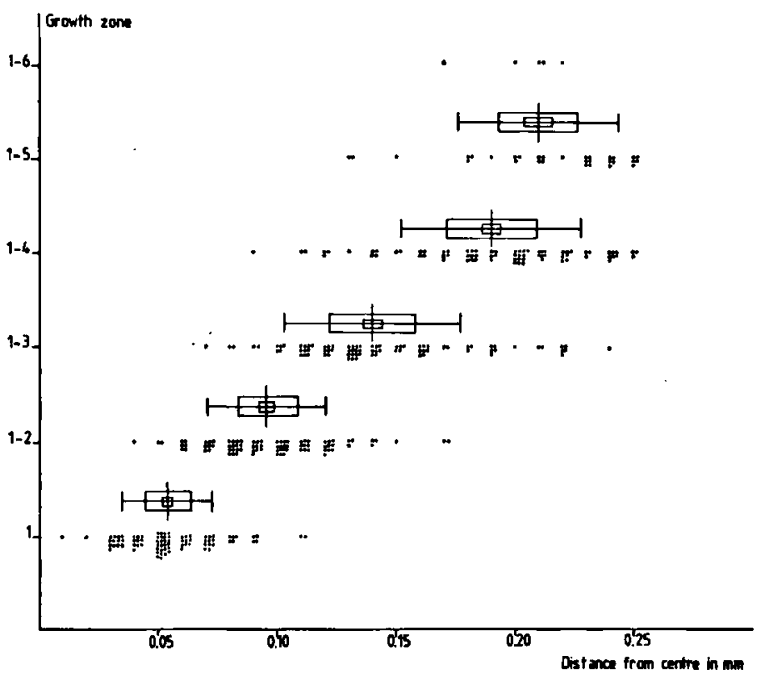

Fig. 9. Distance of the successive opaque border lines from the centre of the otoliths of $\mathbf{8 3}$ glass eels from IJmuiden, caught 17-V-'79. For further explanation see fig. 4. 
TABLE VIII

Numbers of growth zones in otoliths from samples of glass eels from Nantes and Bordeaux.

\begin{tabular}{crc}
\hline$N$ of growth zones & $N$ of animals & $\begin{array}{c}\text { \% of total } \\
\text { number }\end{array}$ \\
\hline Bordeaux $(N=95)$ & & \\
$2+$ & 4 & 4.2 \\
$3+$ & 58 & 61.0 \\
$4+$ & 31 & 32.6 \\
$5+$ & 2 & 2.1 \\
$6+$ & - & - \\
Nantes $(N=46)$ & & \\
$2+$ & 1 & 2.2 \\
$3+$ & 15 & 32.6 \\
$4+$ & 25 & 54.3 \\
$5+$ & 4 & 8.7 \\
$6+$ & 1 & 2.2 \\
\hline
\end{tabular}

TABLE IX

Width of the successive growth layers (mm) in the otoliths of glass eels from Bordeaux and Nantes.

growth layer no. $N$ mean variance S.D. S.E.

\begin{tabular}{crrrrr}
\hline Bordeaux & 10 -III-'79 & & & & \\
1 & 95 & 0.045 & 0.0003 & 0.017 & 0.002 \\
2 & 95 & 0.044 & 0.0001 & 0.012 & 0.001 \\
3 & 95 & 0.045 & 0.0004 & 0.020 & 0.002 \\
4 & 89 & 0.068 & 0.0007 & 0.026 & 0.003 \\
5 & 29 & 0.053 & 0.0008 & 0.028 & 0.005
\end{tabular}

Nantes 20-III-'79

\begin{tabular}{llllll}
1 & 46 & 0.048 & 0.0003 & 0.016 & 0.002 \\
2 & 46 & 0.038 & 0.0001 & 0.009 & 0.001 \\
3 & 46 & 0.035 & 0.0002 & 0.014 & 0.002 \\
4 & 45 & 0.055 & 0.0007 & 0.026 & 0.004 \\
5 & 29 & 0.055 & 0.0008 & 0.027 & 0.005 \\
\hline
\end{tabular}

The relation between the numbers of growth layers and the length of the glass eels from Nantes and Bordeaux are given in figs. 11 and 14 , respectively. These plots are likewise nearly identical to those given for animals caught at various sites along the Dutch coast (fig. 7). Here too, no relation exists between the length of the glass eels and their age.

From 95 animals caught near Bordeaux and

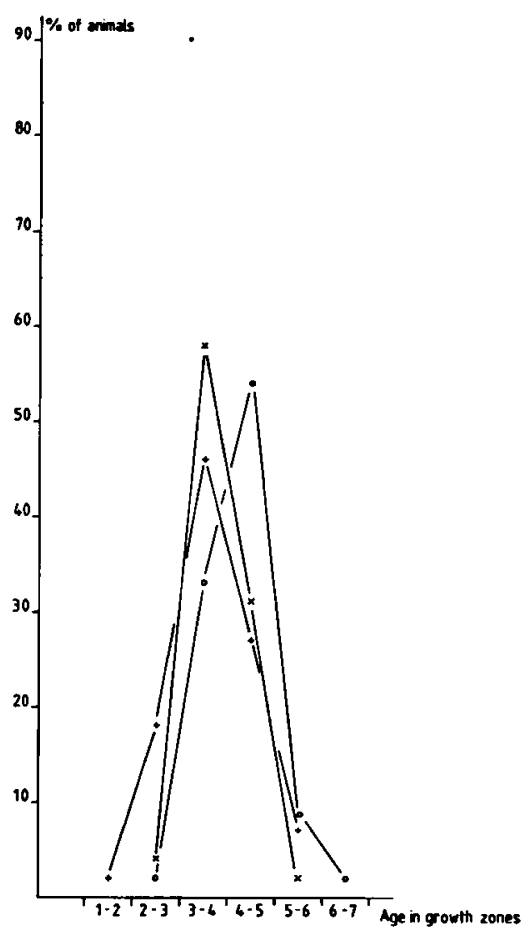

Fig. 10. Percentages of the total numbers of glass eels arranged according to the numbers of growth zones in their otoliths. The samples are taken near Nantes (o), Bordeaux $(x)$ and IJmuiden $(+)$.

from 46 caught near Nantes the width of the successive growth layers could be measured. The results are given in table IX and plotted in figs. $12-13$ and $15-16$, respectively.

In fact there is no clear difference between the results from the samples from IJmuiden and those from Nantes and Bordeaux.

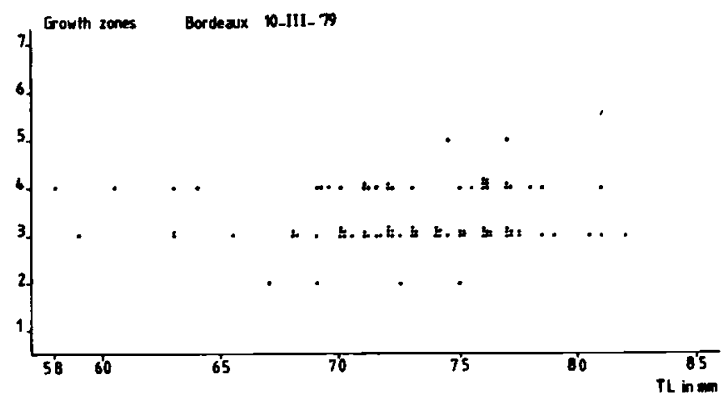

Fig. 11. The age-length relation plotted for the sample from Bordeaux. 


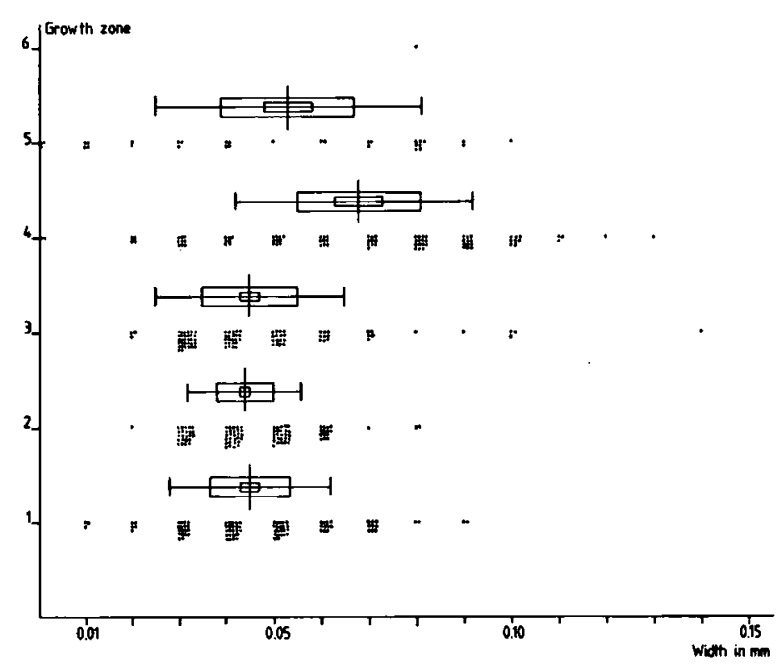

Fig. 12. Width of the successive growth zones in the otoliths of 95 glass eels from Bordeaux. For further explanation see fig. 4 .

\section{DISCUSSION}

The translucent growth zone and the opaque border lines in the otoliths of $A$. anguilla show the same features as those shown by the otoliths of $A$. rostrata, described and depicted by Liew (1974). They also fit the descriptions given by Brothers et al. (1976). Each growth zone, including a wide translucent zone and one or a few narrow opaque rings, is by these authors considered to represent a complete growth cycle. This is supported by the fact that the successive zones in an otolith and also in a series of otoliths, are identical. They are not caused by e.g. changes in water temperature met with during migration through various water bodies, because these are far more irregular.

The measurements show that the growth zones vary in width mainly between 0.03 and $0.07 \mathrm{~mm}$. This also means that the increase of the otolith diameter is fairly regular and - in a graph - is along a line which forms an angle of about $45^{\circ}$ with the horizontal axis. In most cases, in the translucent part of any growth zone 13 very regular interspaced fine rings are present. When taking Liew's (1974) results into account, it seems most likely that the growth zones are annual increments, implying that the

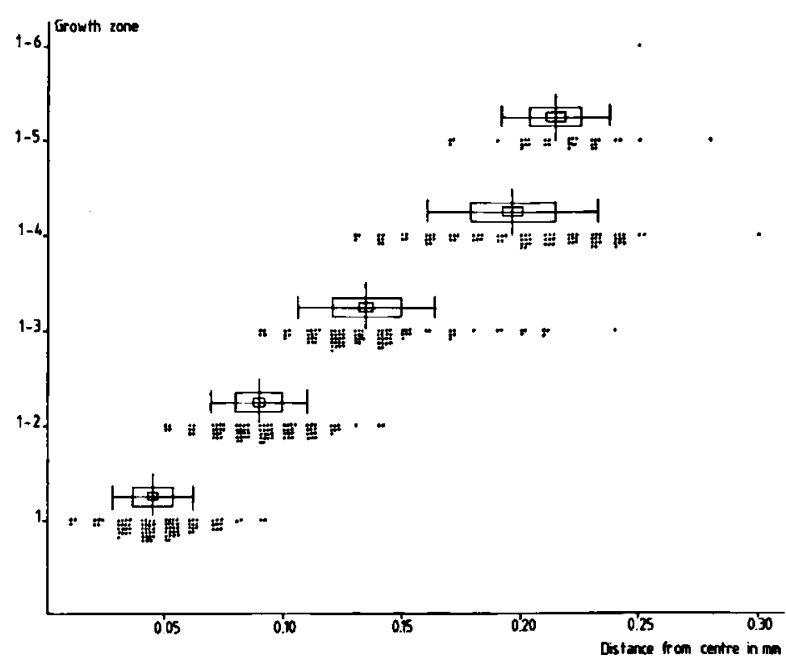

Fig. 13. Distance of the successive opaque border lines from the centre of the otoliths of 95 glass eels from Bordeaux. For further explanation see fig. 4.

glass eels arriving along the Dutch and French coasts vary between about two to about six years in age.

If, otherwise, it is supposed that the growth zones are e.g. monthly increments, the duration of the migration of the leptocephali and

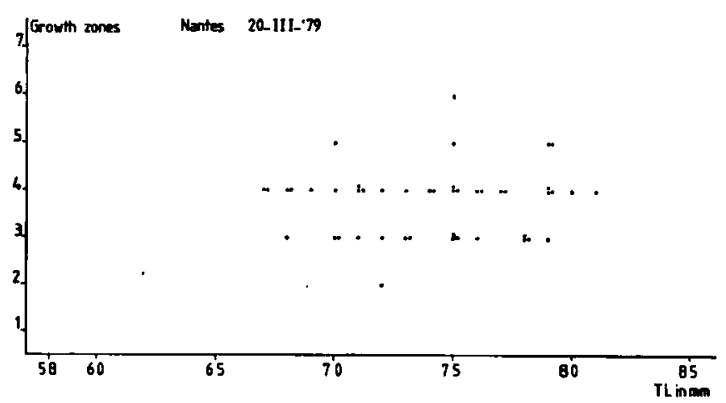

Fig. 14. The age-length relation plotted for the sample from Nantes.

glass eels should be unreasonably short. The migration from the Sargasso Sea towards the European continent should then take about two to seven months, which seems impossible.

Whatever the growth zones may indicate, annual increments or otherwise, they surely demonstrate that the animals have gone through different growth- and life-histories when they enter fresh water. 


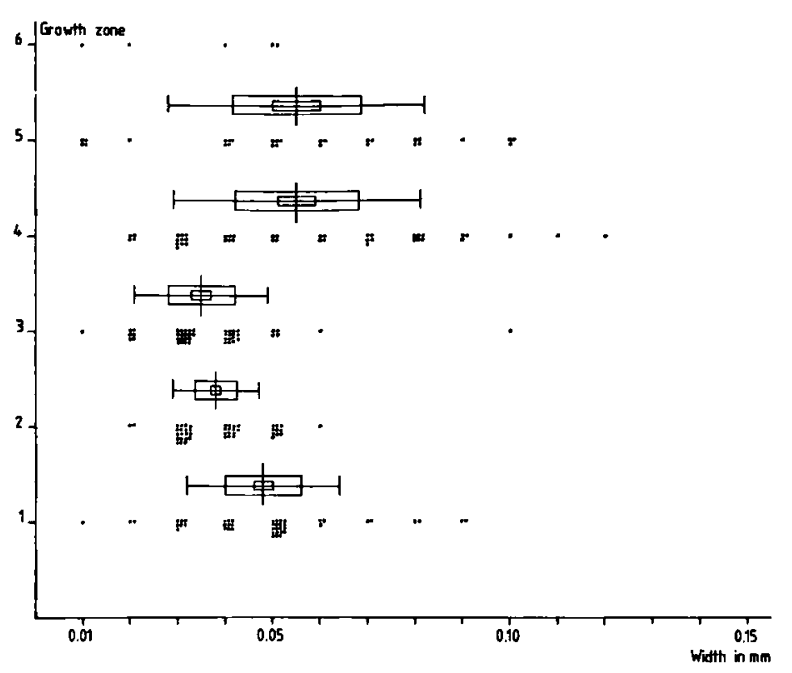

Fig. 15. Width of the successive growth zones in the otoliths of 46 glass eels from Nantes. For further explanation see fig. 4 .

Oceanographic evidence demonstrates that floating objects need at least ten months to drift from the Florida Strait to Great Britain, whereas turtles can cross the Atlantic in about one year (Brongersma, 1967). The distribution of eel larvae in the North Atlantic does not match with Worthington's (1976) opinion about the circulation system. It fits better with the current ideas about the circulation in the North Atlantic, although a number of points are then questionable as well.

In our opinion it seems more likely that the eel larvae use the currents as directional vectors rather than as means of transportation. Their movements in the North Atlantic towards the European continent seems to be far from passive. This is supported by the fact that they can swim vigorously and that in larvae from the central North Atlantic their senses for orientation, viz. smell, vision and inner ear, are very well developed.

The fact that about $60 \%$ of the glass eels examined had two or three growth zones in their otoliths is not surprising. It is, however, the remaining $40 \%$ with four or more growth zones, that puts question marks to the current ideas about the migration of leptocephali and glass eels in the North Atlantic. These results are not

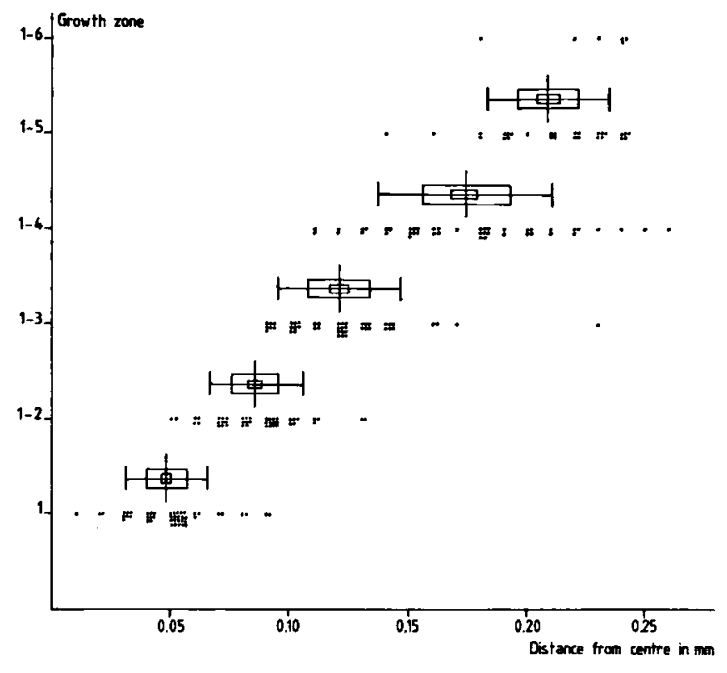

Fig. 16. Distance of the successive opaque border lines from the centre of the otoliths of 46 glass eels from Nantes. For further explanation see fig. 4 .

in agreement with Schmidt's (1922; 1923) idea that the migration of leptocephali of $A$. anguilla from the Sargasso Sea towards the European continental shelf lasts about three years. His views were mainly based on the distribution of length classes of leptocephali over the North Atlantic. Meanwhile, the age-length relation is questionable.

The eel larvae caught in the mid North Atlantic and studied by us had all three complete growth zones in their otoliths. They also had a high number of preanal myomeres and a short postanal distance. These animals were uniform, also with respect to their transparency, though one sample was caught in April 1980 and the other in October 1981.

Most of the larvae caught off the Portuguese coast had four complete growth zones in their otoliths, a low number of preanal myomeres and a varying postanal length of more than $40 \%$ of the total length. This, together with the disappeared transparency indicates that here the process of metamorphosis was developing, though most animals still had the typical larval shape. Moreover, about $30 \%$ of these animals appeared to lag behind in their development. These still had a high number of preanal myomeres, a short postanal distance and they 
showed the same transparency as those caught in the mid North Atlantic, when preserved in $70 \%$ alcohol. In three cases the shape of the animals had changed in such a way that behind the head and in the tail the animals were somewhat constricted.

It is clear that the Portuguese larvae are in different stages of metamorphosis, contrary to what is seen in the samples taken in the mid North Atlantic, meaning that some larvae stay longer in the ocean than others do.

The present data indicate that the age composition and developmental stage of the larvae in the mid North Atlantic is homogenous and that the differences in age of the larvae come into existence along the continental shelf. Hence, the great diversity in age of the glass eels has developed along the continental shelf, where, as we know now, some larvae are soon ready to go into metamorphosis, while others take a longer time to reach this stage. Consequently, a certain number of eel larvae has a prolonged stay in the ocean.

At this moment there are no data available about the ages of eel larvae caught further to the north, e.g. along the continental slope northwest, west and southwest of Ireland. Here the situation is completely different from that off the Portuguese coast, which is also due to the very wide continental shelf. So, it is still difficult to explain fully the existing variation in age of the glass eels.

Marshall (1979: 449, 451) states: "In eels, after the yolk has gone, the larvae grow into leptocephali and become planktonic - in the European freshwater eel (Anguilla anguilla) for about $2 \frac{1}{2}$ to 3 years - before metamorphosis. Their growth and survival for long periods is puzzling, for food is never found in the gut. After close study of leptocephali of the bandtooth conger eel, Ariosoma balearicum, Hulet (1978) suggested that before metamorphosis leptocephali derive their nutrition from dissolved and minute particulate material in the sea, and there is preliminary evidence (from tracer work) of their uptake of solutes (Hulet, in litt.). The buccal lining of the leptocephalus of Ariosoma, like that over the tentacles of beardworms, bears myriads of microvillae."

\section{ACKNOWLEDGEMENTS}

The authors express their gratitude to Dr. C. L. Deelder, W. Heermans and L. A. van Willigen of the Eel Department of the Netherlands Institute for Fishery Investigations (R.I.V.O.) IJmuiden, for providing the series of samples of glass eels, and also to the captain, officers and crew of the F.R.V. "Tridens" for their cooperation in fishing eel larvae. Furthermore, they are very grateful to Dr. H. Nijssen, Prof. Dr. S. van der Spoel and Dr. C. L. Deelder for their criticism and comments.

\section{REFERENCES}

Brongersma, L. D., 1967. Guide for the identification of stranded turtles on British coasts. Publs. Br. Mus. nat. Hist., 659: 1-23 (Trustees British Museum (Natural History), London).

Brothers, E. B., C. F. Mathews \& R. Lasker, 1976. Daily growth increments in otoliths from larval and adult fishes. Fishery Bull., 74 (1): 1-8.

Deelder, C. L., 1970. Synopsis of biological data on the eel Anguilla anguilla (Linnaeus, 1758). EIFAC/FAO Fish. Synopsis, 80: [i-iv], i-iii, 1-8, 1, 1-41, 1, 1-5, 1, 1, 1-10.

Ehrenbaum, E. \& H. Marukawa, 1913. Über Altersbestimmung und Wachstum beim Aal. $Z$. Fisch., 14: 89-127, Taf. IV-V.

Ford, E., 1931. Changes in length during the larval life and metamorphosis of the freshwater eel (Anguilla vulgaris Turt.). J. mar. biol. Ass. U.K., 17: 987-1000.

Gilson, G., 1908. L'Anguille, sa reproduction, ses migrations et son intérêt économique en Belgique. Annls. Soc. r. zool. malacol. Belg., 43: 7-58.

Grassi, G. B., 1896. The reproduction and metamorphosis of the common eel (Anguilla vulgaris). Q. J. microsc. Sci., 39: 371-385.

Harden Jones, F. R., 1970. Fish migration: i-viii, 1-325 (chapter The eel: 69-85) (Edward Arnold Ltd., London).

Heermans, W. \& J. A. van Willigen, 1982. Onderzoek naar de lengtesamenstelling, het gewicht en het voorkomen van naar de Nederlandse binnenwateren trekkende glasaal, Anguilla anguilla L. R.I.V.O. Rapport, ZA 82-01: 1-25.

Hulet, W. H., 1978. Structure and functional development of the eel leptocephalus Ariosoma balearicum (De la Roche, 1890). Phil. Trans. R. Soc. Lond., (B) 282 (987): 107-138.

LiEw, P. K. L., 1974. Age determination of American eels based on the structure of their otoliths. In: T. B. Bagenal ed., The proceedings of an international symposium on the ageing of fish: 124-136 (Unwin Brothers Ltd., The Gresham Press, Old Woking, Surrey).

Marshall, N. B., 1979. Developments in deep-sea biology: i-x, 1-566 (Blandford Press, Poole, Dorset). 
Schmidt, J., 1922. The breeding places of the eel. Phil. Trans. R. Soc. Lond., (B) 211: 179-208.

- , 1923. Die Laichplätze des Flussaales. Int. Revue ges. Hydrobiol. Hydrogr., 11: 1-40, Taf. I-IV.

Sснотн, M., 1982. Taxonomic studies on the 0-group eel larvae (Anguilla sp.) caught in the Sargasso Sea in 1979. Helgoländer Meeresunters., 35: 279-287.

Sinha, V. R. P. J. W. Jones, 1975. The European freshwater eel. With a chapter on eel fisheries by $\mathbf{R}$. S. Pritchett: i-xv, 1-146 (Liverpool University Press, Liverpool).

Strubberg, A., 1913. The metamorphosis of elvers as influenced by outward conditions. Some experiments. Meddr. Kommn. Havunders. (Fisk), 4 (3): 1-11.

TEsch, F. W., 1980. Occurrence of eel Anguilla anguilla larvae west of the European continental shelf,
1971-1977. Envir. Biol. Fishes, 5 (3): 185-190.

TuCKER, D. W., 1959. A new solution to the eel problem. Nature, Lond., 183: 495-501.

UtRECht, W. L. vaN, 1983. Saurenchelys halimyon, a new species of nettastomid eel, with comments on Saurenchelys cancrivora Peters, 1864, and a preliminary list of larval and metamorphosed Anguilliformes caught in the mid North Atlantic. Bijdr. Dierk., 53 (2): 227-232.

Vladikov, V. D. \& H. March, 1975. Distribution of leptocephali of the two species of Anguilla in the western North Atlantic, based on collections made between 1933 and 1968. Syllogeus, 6: 1-38.

Worthington, L. V., 1976. On the North Atlantic circulation. Johns Hopkins Oceanogr. Stud., 6: 1-110. 